\title{
THE IMPACT OF RUSSIA-CHINA TRADE RELATIONSHIP ON THE U.S. ECONOMY
}

\author{
Nikolay Megits \\ Webster University, St. Louis, MO
}

\begin{abstract}
Over the years, bilateral trade between China and Russia experience many turbulences but in recent years has grown rapidly. Their relationship has evolved in such a way that they have come to rely on each other. The reason why Russian-Chinese relationship improved is because of U.S. and EU economic sanctions due to Russian invasion of Crimea and military attacks of Eastern Ukrainian territory. Russia needs China for funding and infrastructure development, and China needs Russia to feed its large energy needs. China and Russia have a strong trade partnership that extends into many different sectors throughout each country. While deep mistrust exists between both sides, China and Russia have proud cultures that desire to be viewed as global powers and believe their relationship with each other will advance that objective. Further, both countries view the West as a hindrance to their overall trade goals, and this marriage of convenience strengthens their position in global affairs which could result in far reaching implications for the world. This paper provides a short overview of how the China-Russia relationship developed, where it is at now, how it could be harmed, and how a stronger trade relationship with the U.S. and rest of the world could subvert those fears. It will also provide recommendations based on a solid foundational understanding of gl obal trade and management.
\end{abstract}

Keywords: International Trade, Political Sanctions, Russia, China, Eastern Europe

DOI: http://dx.doi.org/10.15549/jeecar.v3i2.135

\section{INTRODUCTION}

\section{A Short History}

How will the China-Russia strategic partnership ultimately impact the United States and the world? For the past 65 years, China and Russia have had a steady building trade relationship. Currently, the China-Russia relationship is considered as a partnership. They do not see themselves as allies, but they do both actively support one another. The relationship started to progress in 1992 when Russia and China signed a joint statement on the foundation for bilateral ties. In 1996, a partnership of strategic coordination was developed. When the Treaty of Good-Neighborliness and Friendly Cooperation was signed in 2001, the strategic partnership between the two countries was formally institutionalized and was based on, "mutual respect for sovereignty and territorial integrity, mutual nonaggression, noninterference in each other's internal affairs, equality and mutual benefit, and peaceful coexistence" (Ying, 2016). Russia and China then signed a statement that deepened their comprehensive strategic partnership of coordination in 2013 (Li, 2014). This brought the Russia-China relationship to a whole new level where it stands today. The 
situation of their economic relationship changed dramatically at the beginning of March 2014, after Russian occupation of Crimea. European Union and the United states applied a serious of economic sanctions. Because of sanctions, the rate fell to a record low $\$ 1=36.75$ rubles. The Russian Ruble depreciated approximately $20 \%$ between the end of December 2013, and the end of August 2014. The Ruble fall resulted in new troubles for Russian economy. Primarily, this means accelerated inflation and decrease of personal consumption. Russian government had no other option than seek for Chinese economic cooperation, as they have done many times in a past.

\section{Trading Partners}

China and Russia are seen as complements to one another. China is known for its factory worker population, where Russia has many labor shortages. China holds advantages in telecommunications, while Russia has advantages in nuclear energy (Li, 2014). China is a major buyer of Russia's large export of energy because China is not able to produce the amount of energy that they need on their own. They also did not want to rely on Europe for all its oil and gas sales. Because of this, making a deal with Russia seemed like a good idea to China due to Russia being the number one exporter of gas and number two exporter of oil amongst the world (Sidorenko, 2013). Russia on the other hand, has seen European oil and gas sales shrink since 2008 due to the global downturn, which has not yet recovered. According to Woods MacKenzie, a consulting firm, "The International Energy Agency does not expect gas demand in the European Union to rise back above 2010 levels until at earliest 2020" (Robertson, 2013). As a result of the current realities, Russia is desperate to sell the resources it has in abundance and has pivoted to the east. Meanwhile, China has actively been seeking ways to diversify how it gets energy from outside sources. Ultimately, Russia and China have determined that strengthening their energy trade relationship provides an opportunity for both, and they are committed to building the relationship going forward.
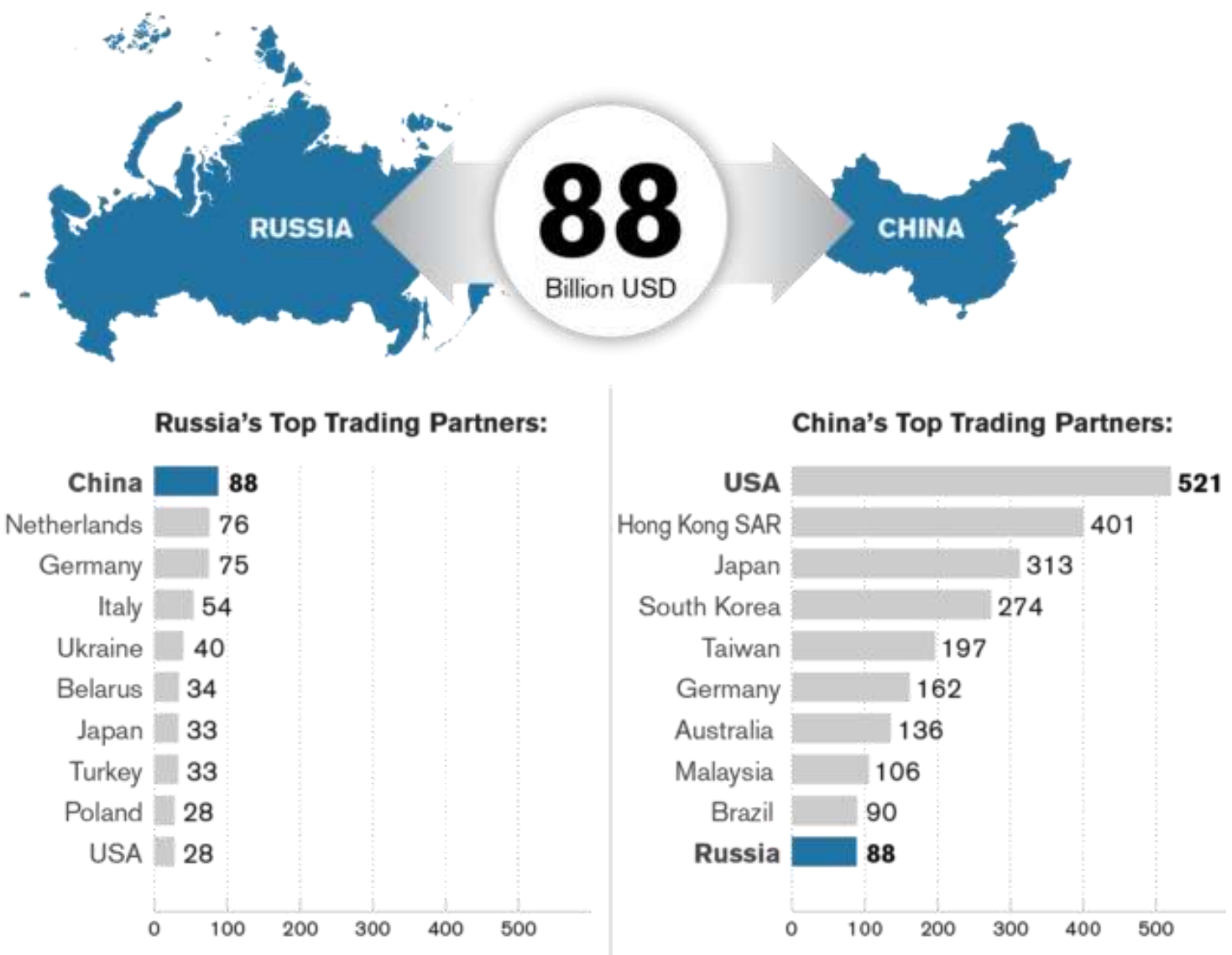

Figure 1. Trade between Russia and China (Recknagel, 2015) 


\section{Military Capabilities and Shifting Trade Dynamics}

Russia and China are increasing and modernizing their military capabilities (Gelb, 2013). This relationship has potential to evolve into a force that could have threatening implications which places major threats upon the rest of the world, especially the United States. These include collusion to depress United States power and influence, strategic triangular diplomacy and combined military might which would threaten the world. Currently, China receives their weapons and military from Russia. China has demand for the Su-27 fighter, and the S-300 air defense missile systems, as well as other defense systems (BBC Monitoring Former Soviet Union, 2014). In 2005, Russia and China carried out their first ever joint military drill. In 2013, President Xi was invited to visit Russia's command center by the Russian Defense Ministry. Military drills between Russia and China are now conducted yearly on a much larger scale (Li, 2014). However, it is important to recognize that China and Russia need more from the United States and the European Union than from each other (Gelb, 2013). This is made even clearer by actual trade relationships that exist currently. See Figure below.

As evidenced above, the United States is China's number one trading partner, and Russia comes in at tenth. For Russia, the European Union (EU) is the top trading partner followed by China, and the United States is fifth. For Russia in particular, Putin may do better for his country by improving his relationships with the EU and mending relationships with Ukraine. On the other hand, the United States is not immune to criticism. Developing foreign policy can help rebuild trading relationships with the China-Russia partnership while also furthering the interests of all three nations. This could also help reduce tensions that they may face as a result of their political alliances or lack thereof. Further, it will help push Russia out of its corner of an economic slump and perhaps soften Putin's affinity for annexation campaigns.

\section{LITERATURE REVIEW}

The articles chosen for this topic contain information pertaining to several aspects of the relationship between Russia and China. They describe the history between the two countries and some of the issues that have risen as the two have become more intertwined. Also addressed are the implications of such a partnership on the world community, and how it can affect United States interests. Interestingly, the articles point to a level of mistrust between the two and how the relationship remains highly complex and is not guaranteed to be a successful endeavor.

\section{"Development of China-Russia Relations"}

The article chosen as the basis for the literature review is by Jing-Yun Hsu called "Development of China-Russia Relations." In the article Hsu argues that Russia and China have formed a strategic partnership that seems to lack a solid foundation, yet despite this, it would be a mistake to minimize the impact such a rising partnership can have on the world. Hsu points out how China is a rising power in the world and that, "in 1980, the Beijing government joined the World Bank, and China drew closer not only to the United States but to the whole world global capitalist system" (Hsu, 2014).

Hsu also explains how Russia and China's relationship counters American hegemony superiority by stating that, "the two governments frequently have called for a multipolar world in which Russia and China would occupy key positions along with Europe, the United States, and perhaps Japan" (Hsu, 2014). Alarmingly, the article states that Russia and China militaries have also cultivated a relationship and both countries purchase arms, and military equipment from each other. However, as a source of potential friction, "China's arms industry can now match Soviet-era technologies. In addition, Russia is reluctant to provide sophisticated technology and advanced weapons to China because they could be used against Russia if relations deteriorate" (Hsu, 2014). Despite this potential friction, in Kenneth Timmerman's article, "China and Russia Align Against the U.S.," an intelligence analyst claims that China and Russia are entertaining the idea of significant military sales to include: "Direct purchases of nuclear submarines and Long-range nuclear missiles" (Timmerman, 2001). Unlike Hsu's article, Timmerman's article seems to believe that despite Russia and China's differences, combating U.S. dominance on the world stage is a strong enough motivator to overcome differences. 
Conclusions from "Development of ChinaRussia Relations"

Finally, Hsu states that, "China has become more important in Russia's trade than Russia in China's trade" (Hsu, 2014). Russia's relationship with the West has been at its lowest point since the Cold War and has had to move its focus from the West to the East. Also, they have not diversified its export business and continue to solely focus on natural resources. Meanwhile, China has been nervous about how it imports its energy needs, yet at the same time, does not have to rely on oil and gas from Europe or Russia only. Hsu goes into detail about trade statistics and quotes Chinese customs statistics that state, "rising from US $\$ 5.86$ billion in 1992 to US $\$ 48.2$ billion in 2007, there are good reasons for expecting trade volume to expand in the future. In 2008, the level of bilateral trade reached US\$56.83 billion" (Hsu, 2014).

\section{"How China Sees Russia"}

Fu Ying's article titled, "How China Sees Russia," acknowledges Hus's idea that China and Russia are not as close as their relationship would seem. The article posits that "Beijing and Moscow are close, but not allies" (Ying, 2016). Ying explains that the relationship is "vulnerable, contingent, and marked by uncertainties - "a marriage of convenience" (Ying, 2016). Ying also explains how the Russia and China relationship is perceived by the rest of the world. The Russian and Chinese governments officially state that they want their relationship to be positive and constructive. The west believes their intentions are much more sinister and are concerned that eventually it will negatively impact the United States and the world. In the article he claims that, "strategic and ideological factors form the basis of Chinese-Russian ties and that the two countries - both of which see the United States as a possible obstacle to their objectives - will eventually form an anti-U.S., anti-western alliance" (Ying, 2016). This alliance has already shown itself as Ying explains how Russia and China have acted in mutual interest on the world stage. Through the UN and the Security Council, of which both are sitting members, China has backed Russia on resolutions concerning Syria. Also, China has turned a blind eye on Russia's involvement in Crimea, to the astonishment of the United States and others. In a BBC article it states, "Russia has an ally of China in voting in the UN security Council (as a rule, Russia and
China veto proposals by Western countries together, as happened last week in relation to the idea of handing the "Syrian file" over to the International Criminal Court)" (BBC Monitoring Former Soviet Union, 2014).

\section{Conclusions from "How China Sees Russia"}

Ying believes that, "Relations among China, Russia, and the United States currently resemble a scalene triangle, in which the greatest distances between the three points lies between Moscow and Washington. Within this triangle, ChineseRussian relations are the most positive and stable" (Ying, 2016).

In sum, the articles tend to convey that Russia and China are reluctant partners and are together only because they have specific trade needs from each other at this moment in history. Also, without stating it directly, and with direct comments from the Russian and Chinese governments to the contrary, the articles lean toward the belief that despite their differences, both believe their partnership will help them challenge United States dominance in the world.

\section{STATEMENT OF RELAVENT PRINCIPLES TO BE APPLIED}

\section{International Trading}

China and Russia are both engaged in international trade. China exports electronic equipment, machinery and textiles, and Russia is a large exporter energy. In December 2015, China and Russia had their central banks sign a memorandum of understanding. The intent of this was to expand cooperation by promoting local currency settlements, bank card issuance, access to local currency bond markets, and credit-rating partnerships. Simultaneously, the Russian Direct Investment Fund (RDIF), Vnesheconombank (VEB) and the China-Eurasia Economic Fund (CEECF) announced that the financing of Chinese exports to Russia would occur; as well as the guidance for the flow of Chinese investment into the Russian Far East and Trans-Baikal areas.

China is Russia's largest single trading partner, with $\$ 90$ billion in trade volume that occurred in 2013 projected to only keep rising. In Comparison, Russia is China's ninth largest trade partner. Between 2003 and 2012, trade between China and Russia grew at an average of $26.4 \%$ per year (Sidorenko, 2011). By 2020, both China and Russia estimate the trade volume to be at $\$ 200$ billion (Ding, 2014). In order to accomplish this 
goal of $\$ 200$ billion, over 30 agreements have been signed including areas in economy and trade, foreign affairs, infrastructure, technology and innovation, agriculture, finance, energy, media, internet, and sports (Sidorenko, 2011).

Russia became a member state of the World Trade Organization (WTO) in August 2012. This has had a large impact on bilateral and international trade for China and the rest of the world due to trade and economic cooperation that is associated with the WTO. Russia's agreement to the WTO opened new markets for China, but also brought other competitors against China. With this being said, Russia's WTO agreement is still more beneficial for China than it is harmful. First, this agreement was helpful for making the trade system more standardized and improving the trade environment. In the longterm it will ensure stable development of trade and economic cooperation between China and Russia. Second, Russia tariffs were reduced on some goods based on WTO rules which were beneficial for expanding China's exports to Russia. In 2012 Russia's average tariff rate was 12.4 percent. This rate is higher than the tariffs in developed countries and below in developing countries (Soong, 2014).

China's Silk Road Fund agreed to provide 730 million Euros (about $\$ 778$ million) over a 15 -year period for the Yamal liquid natural gas project. In 2015, Russian agribusiness exported to China for the first eleven months of the year increasing by over 14 percent to $\$ 1.2$ billion from the previous year.

As shown below, energy prices have increased more than any other commodity. Energy products presented a much higher price increase than other merchandises between 1995 and 2014. In 2000 there was a turning point where energy prices started to grow. In 2003, there was an upward trend until arriving at a peak in 2008. The reason of falling by $37 \%$ in 2009 was the economic crisis of 2008. Nevertheless, the value in 2009 was still over three times higher than in 1995. The second peak was in 2012, where the value was six times higher than in 1995. Since then, the energy prices had a declining trend, and they turned sharply negative in 2014 when the prices falling by $8 \%$ compared with the year of 2013 (WTO, 2015).

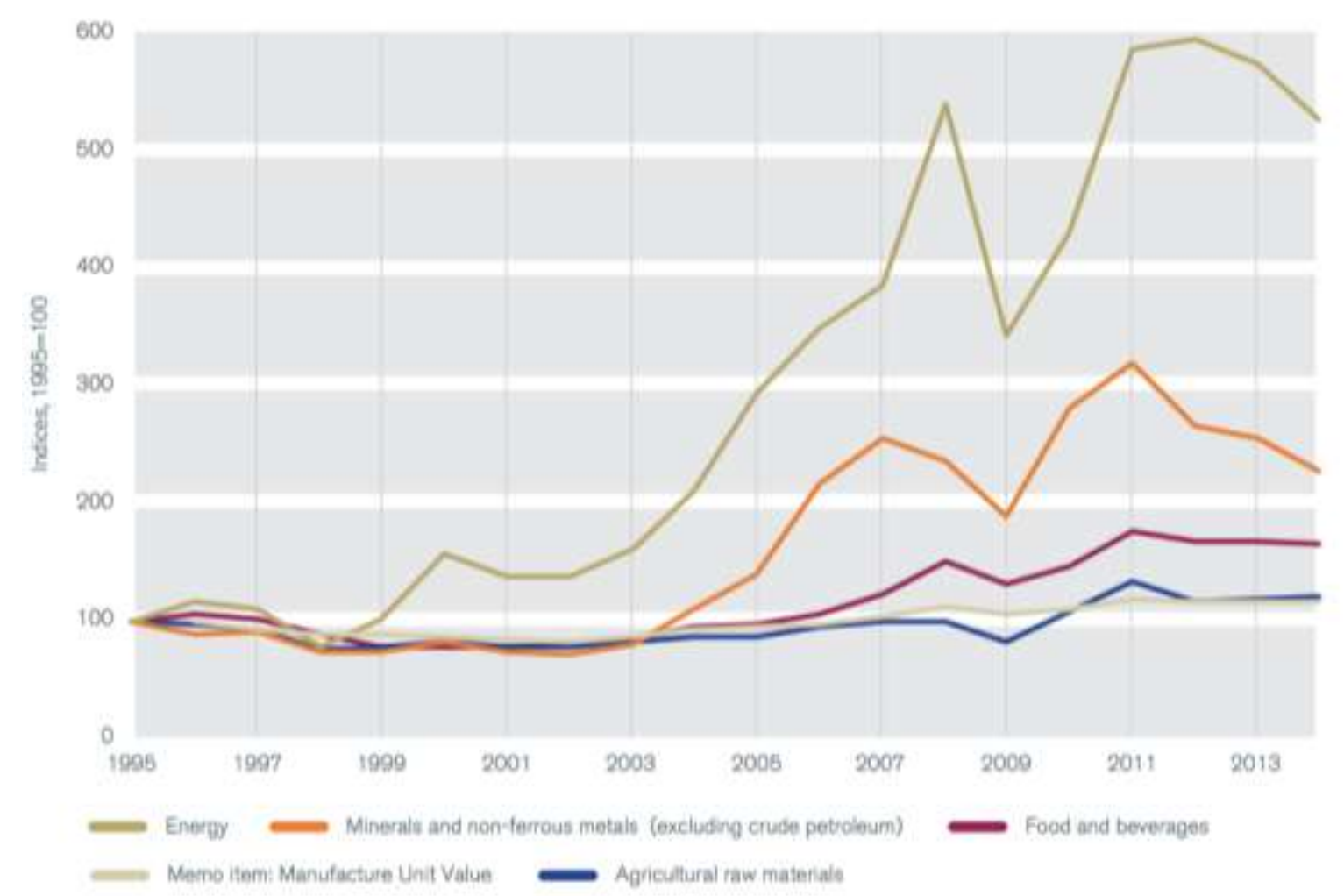

Graph 1. Export Price of Commodities (WTO, 2015)

\section{Foreign Direct Investment}

China-Russia relations are very asymmetric, but they are asymmetric in different ways. In certain areas China dominates. However, Russia has a lot of advantages that China does not have politically. The nature of the China-Russia relation remains to be fully seen (WTO, 2015). 
Natural gas plays a key role in the FDI relationships China has with the world. Particularly because of the price fluctuations that China has between various trading partners. For Russian gas, the final price remains unknown for the trade secret, but it is estimated that China pays Russia around $\$ 350.00 / \mathrm{mcm}(\$ 9.72 / \mathrm{mmBtu})$ (Weitz, 2014). This can be considered high to some, but this was the final deal that China and Russia agreed upon. China's natural gas price from other countries already has FDI included in those areas. China relies on importing natural gas nearly one-quarter of its necessary volume for one year. The average price is $\$ 285.50 / \mathrm{mcm}$ (\$7.93/mmBtu) (Oil Daily, 2011). Compared to China's domestic gas price in the recent decade, the current ex-factory price of gas to industrial users is $\$ 211.00 / \mathrm{mcm}$ ( $\$ 5.87 / \mathrm{mmbtu})$. But the transportation causes the price increase by 50 $70 \%$ of the ex-factory price (Natural Gas Week, 2006). In addition, both countries are well know of their corruption and there is a strong negative impact of corruption on the GDP per capita (Mustapha, 2014).

\section{Natural gas agreements an important step forward, but much work remains to be done}

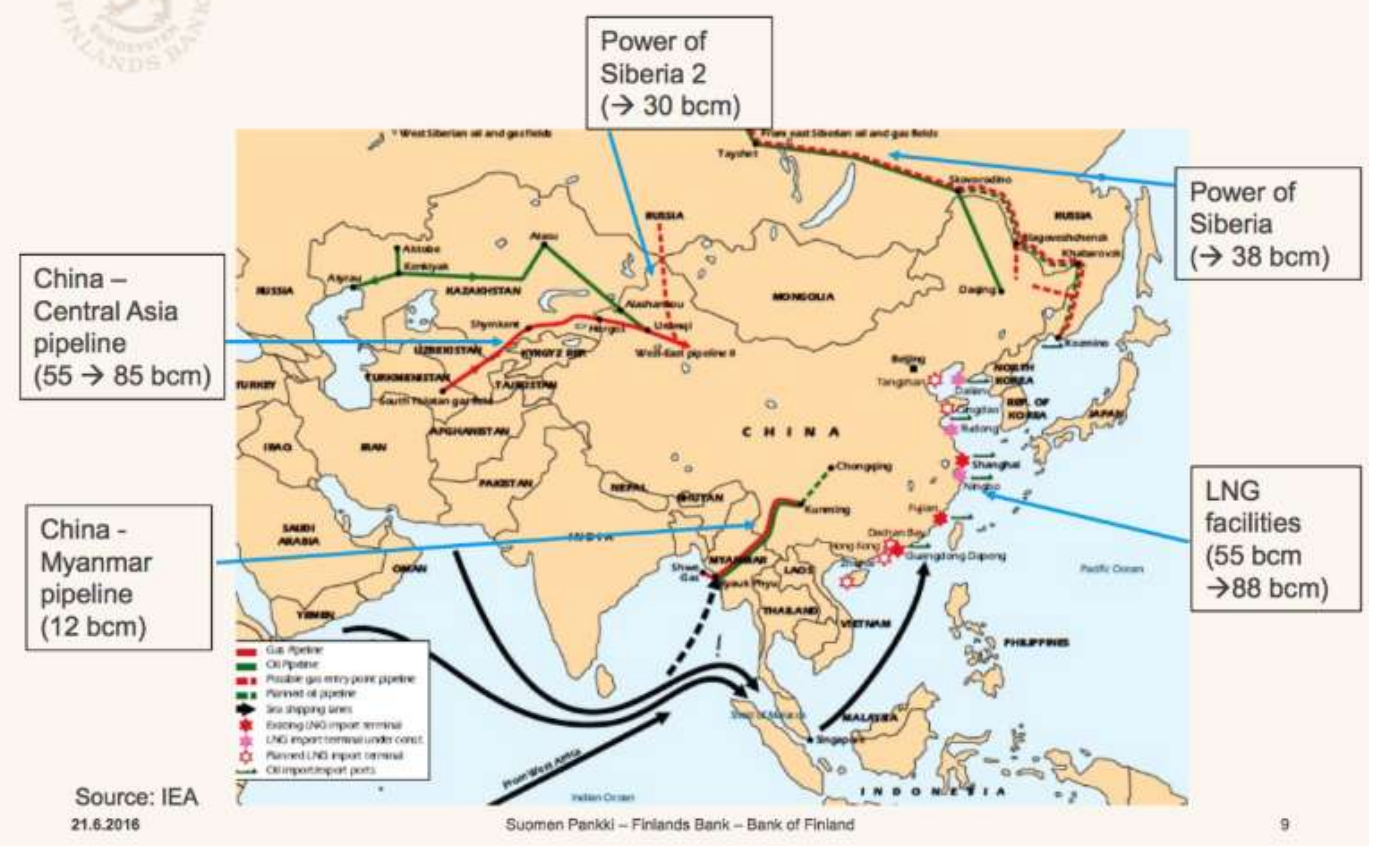

Figure 3. Natural Gas Agreement (Simola, 2016)

Central Asian states are the pivotal areas for the world's economy. To China, they have advantages of the geographic proximity and shared borders. To the world, they have rich energy resources. For China, it has FDI in the countries like Turkmenistan. China has its own exploration firms in those areas, and countries in those areas are mainly providing the natural gas locations. Hence with the relatively low exploration costs, China purchases their gas at a price lower than Russia's (Pahl, 2014).

China invested $\$ 3$ billion in building the Tajik segment of the Turkmenistan-UzbekistanTajikistan-Kyrgyzstan-China gas pipeline. This line is more than 400 kilometers, and it is planned to be completed by the end of 2016. The agreements on the construction were signed in
September 2013. The pipelines are estimated to ship 25 billion cubic meters (bcm) of gas per year. It will boost volumes of Turkmen gas to China up to $65 \mathrm{bcm}$ every year (Central Asia General Newswire, 2013).

As the China-Russia has developed, there are several agreements that they have made between each other. China has promised to invest $\$ 20$ billion into Russia's domestic projects. These projects are focusing on transportation infrastructure, highways, ports and airports. In the long-term run, gas is non-renewable resource (Pahl, 2014). This is a factor that China must consider when creating these partnerships. The implications for ignoring this fact could have strong economic effects. 


\section{Environment}

The environment is an import topic that is being discussed worldwide. For Russia, it has the advantages that in the global warming trend, the volume of exploitable natural gas will be increased in the future. Both China and Russia have goals to maintain the world's environment. According to the United Nations, one of the goals is to ensure access to affordable, reliable, and sustainable energy. For almost every country and place, energy is vital for jobs, security, climate change, and food production. Obtaining the sustainable energy is opportunity for not only China and Russia, but for the entire world as well. Another goal is to take immediate action to fight for climate change and the corresponding impacts. The world is experiencing major changing weather patterns, rising sea levels, and many other extreme weather events are occurring. In this situation, the poorest people are often affected the worst. Climate change does not respect national borders. This issue needs international cooperation to carry developing countries into a low-carbon driven development and economies. Countries signed the Paris Agreement to address the issue (UN, 2016).

Climate change has become the top concern of the world leaders in recent years due to it not changing, the rising concern and it affecting everyone. Measures taken against climate change may have a direct impact on the mode and speed of development. It can be difficult to find the balance on how to maintain efforts to address these climate changes. Economic development is a challenge for the entire world. The EU is the largest group of industrialized countries. China is the largest developing country and currently the largest greenhouse gas emitter in the world. These two both are important in regards to the United Nations Framework Convention on Climate Change (UNFCCC) and the Kyoto Protocol (KP). To some extent, whether the efforts to contain climate change will be successful or not in the coming years will be affected by the positions and policies of the EU and China (Men, 2014).

The EU and China regard each other as partners in some aspects. Since the 1990s, cooperation has been expanding between Brussels and Beijing, with increased institutionalization of their bilateral relations. Hu Jintao, the previous Chinese President stated, "Global climate change has a profound impact on the survival and development of mankind. It is a major challenge facing all countries" (Men, 2014). While trying to defend China's position on climate change, Beijing has realized that work needs to be done internationally. In the absence of United States leadership and United States failure to approve the Kyoto Protocol, the EU sees itself as playing the leading role in global efforts against climate change to effectively reduce greenhouse gas emissions.

\section{Globalization}

China and Russia have developed at a fast rate in economic and trade relations in the midst of a global economic slump. Their partnership is clear throughout the world, where billions of United States dollars are invested in the construction of oil and gas industries. Mineral fuels make up around half of all Chinese imports, but the volume will increase in the near future due to the effects of the new oil pipeline and the gas agreement. If the two states continue down this partnership road, it could challenge the future balance of world power, and eventually result in the change of the world order (Soong, 2014).

When Russia annexed Crimea, the move was considered by the United Nations as an invasion on a sovereign country and sanctions were put into place that have had a devastating effect on the Russian economy. The West cut purchases of Russian oil and gas extensively, and in response, Russia turned its focus onto the east to sell their natural resources. Meanwhile, the deal benefits China in a couple of different ways. First, "The gas deal would ease China's concerns that most of its fuel supplies come through the strategic chokepoint of the Strait of Malacca" (The Economist Intelligence Unit N.A., Inc. 2014). China's worry is that so much of their energy needs filter through the Strait and should relations between the East and West deteriorated, the strategic chokepoint could be cut off by the West. Security for the nation would not be in Chinese hands, but rather would be vulnerable to outside influences, something that is unacceptable to the Chinese government. Second, the deal would "enable them to move away from burning so much coal that pollutes the air in Chinese cities" (The Economist Intelligence Unit N.A., Inc. 2014). Cities like Beijing, Chongqing, Urumqi, and Lanzhou are so polluted and the smog so thick, that you cannot see the sun even at its highest point in the day. In these areas, children and the elder population are at the most risk from complications from the 
pollution. This is a current health hazard that China must address or the result will be an unhealthy population that will overwhelm the health care system in China. This deal in part, addresses this issue. In addition, both China and Russia, being new members of WTO still possess a strong lack of democratic deficit, fairness, openness, and transparencies in decision-making improvements according to WTO regulations (Giannakarou, 2014).

\section{ANALYSIS AND APPLICATION OF PRINCIPLES}

Russia's top exports to China in 2015 included: oil ( $\$ 20.2$ billion), wood ( $\$ 3.1$ billion), nickel, fish, ash, fertilizers, wood pulp, copper, inorganic chemicals and machinery (\$390.6 million). This amounted to $\$ 33.2$ billion which is $2.2 \%$ of its overall imports. On the other hand, China's top exports to Russia in 2015 included: electronic equipment ( $\$ 8.6$ billion), machinery, footwear, clothing, plastics, vehicles, toys, knit clothing, iron/steel products, and organic chemicals (\$796.4 million). This amounted to $\$ 34.1$ billion which is $19.2 \%$ of its overall imports (Sidorenko, 2011).

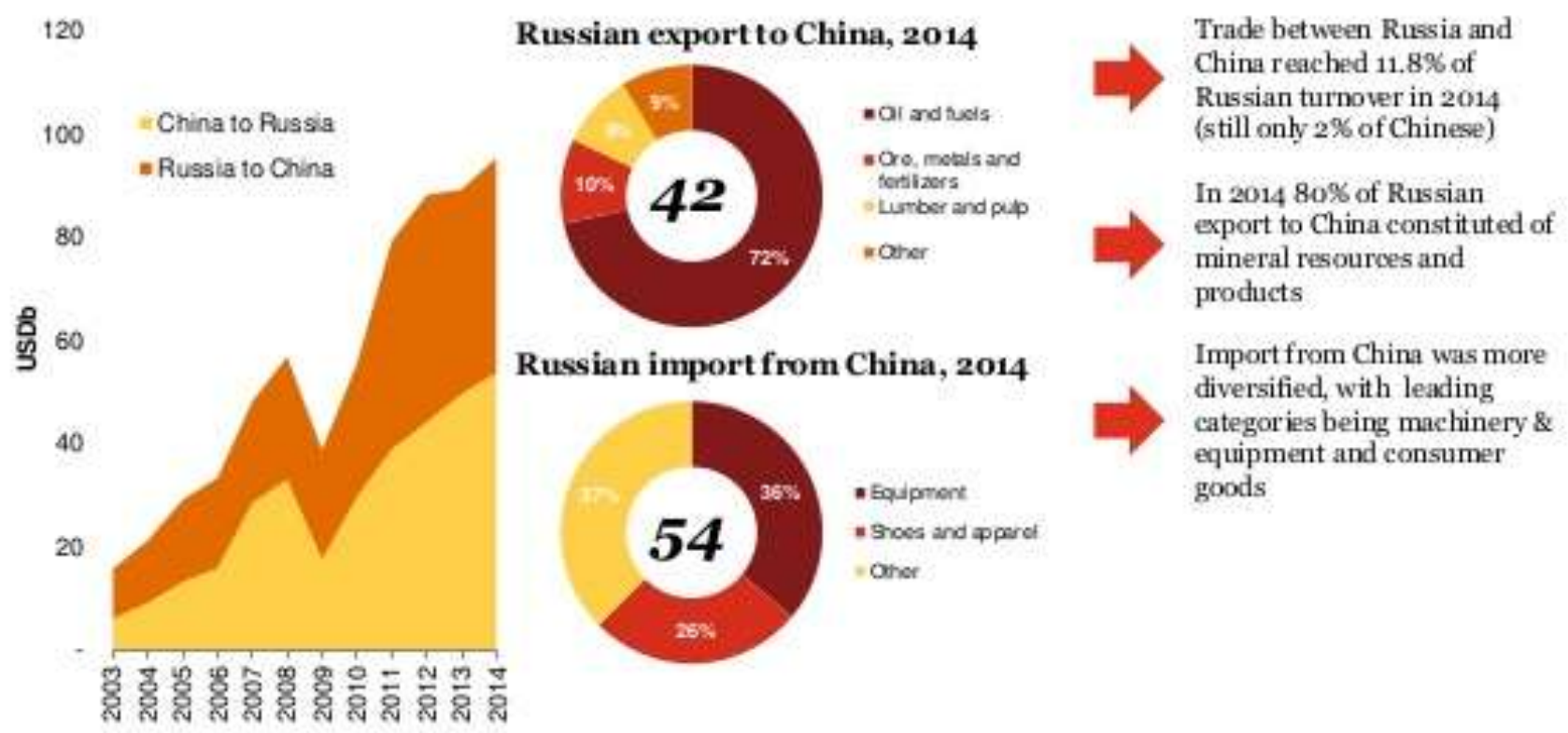

Figure 3. Federal Customs Service of Russia (2016 China-Russia Business Seminar)

Energy makes up the bulk of the trade, with two thirds of Russian exports to China amongst the energy sector. On May 21, 2014 a 30-year gas supply contract was signed between Russia and China. This contract is a $\$ 400$ billion natural gas supply, which will be sent yearly to China through the pipeline until 2044. This volume will have a large impact for China. As a result of this deal, China will provide $\$ 20$ billion for a gas development and infrastructure. The new pipeline where gas will be transported linked Siberian gas fields to China's main consumption centers (Nakano, 2014).

China has been in a fast developing economic environment since the Economic Reform that started in the 1970s. In 2010, China turned into the global largest exporting country. China's rapid growth has made it the world largest energy consumer. Russia, on the other hand, is one of the world's largest energy producers and therefore in a position to fuel China's economy. In January 2011, an oil pipeline linking Daqing in China's Heilongjiang province and Skovorodino, a Russian city, officially began operation. It was expected to transport 15 million tons of crude oil per year, with a 30-million tons per year benchmark set for the immediate future. Bilateral ties have been strong for quite a while, and will likely only get stronger (Soong, 2014). In 2014, it became the largest economic entity, with a gross domestic product (GDP) of $\$ 17.63$ trillion. This shows over ten times increase in its GDP since 1978 (Chaturvedi, 2016).

The China-Russia trade relationship is not the result of the market economy, but is more inclined to the political cooperation. China has had a mixed economy since it started the Economic Reform in 1979. Under the socialist market economy, with the hybrid regulations by plans and by the market, Chinese government 
has the power to connect the trading events with the politics. That means to mobilize capital from the market in exchange of political support from Russia. To a considerable extent, Chinese government promotes a stable business environment. Seeking mutually beneficial cooperation in trade, energy, transportation, nuclear, science and technology, space industry, etc., China-Russia relations are arguably better today than they have been at any point since World War II (Nanako, 2014). The two countries are very asymmetric. In natural gas reserves, Russia dominates. Of course, economically China is much stronger than Russia. Hence China made a concession on natural gas price.

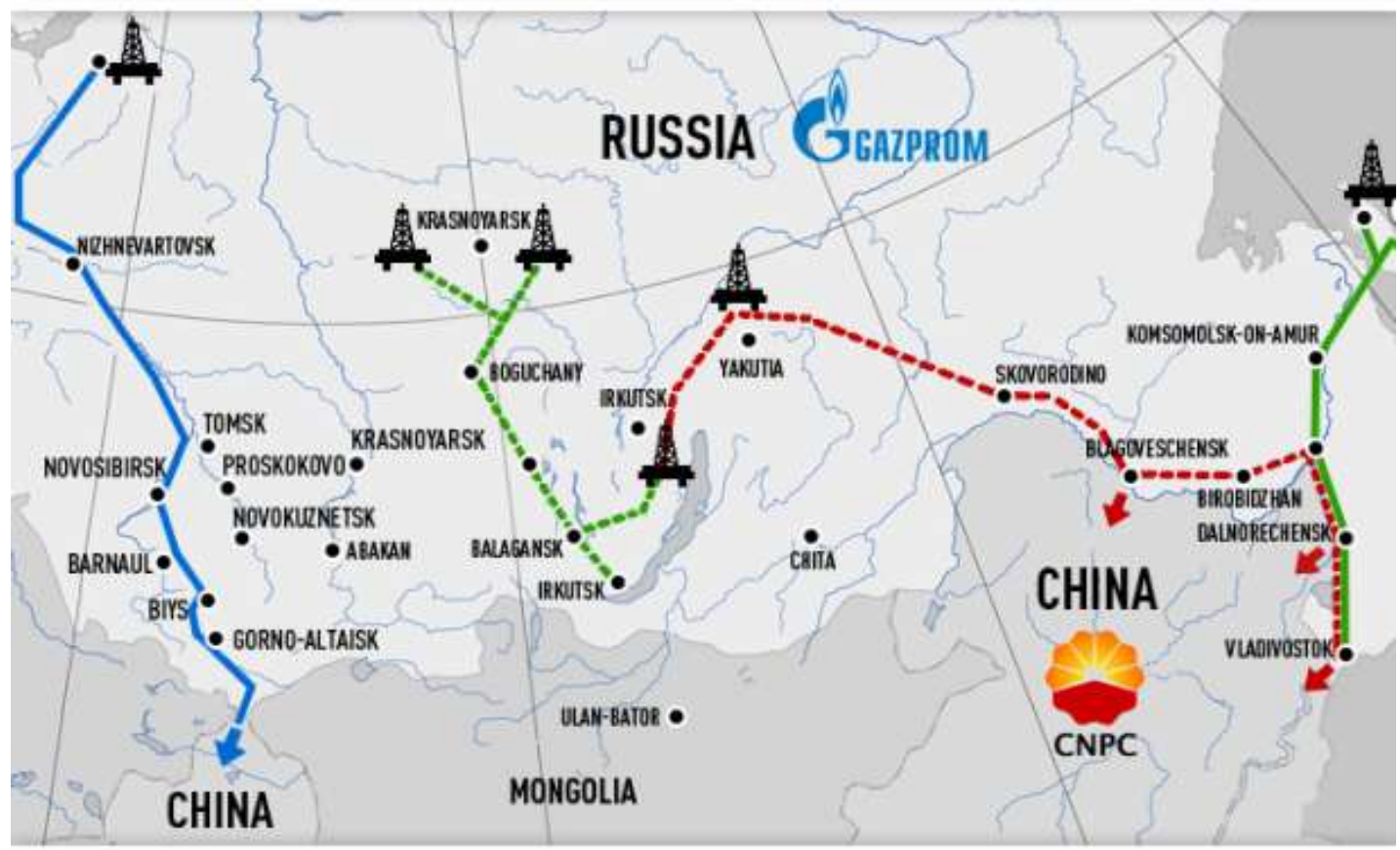

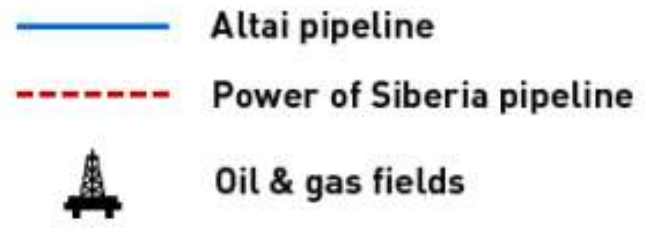

Figure 4. Russia China Gas Pipeline (Nanako, 2014)

Working together amongst the world will be the key in eliminating potential disasters such as climate issues and economy issues. There are many important topics that will not be addressed if mutual respect is not agreed upon.

\section{RECOMMENDATIONS}

\section{Russia}

Russia should consider developing more opportunities for innovation and entrepreneurship. "Russia considers oil and natural gas to be paramount strategic tools of its diplomacy" (Hsu, 2014). This would create more products and services that the Russian Federation could export in an effort to increase trade with the world and thereby increase participation in global markets and reduce political, economic and legal fears other nations have in building lasting relationships with Russia. Putin's Russia has vast resources both human and natural that could be used to encourage creativity. One solution could be to create a product or service that will be needed in the world in the near future. Water will be a scarce resource and Russia has access to many bodies of water and scientists that could develop desalination products, techniques or services that could help literally provide clean, drinking water to the whole world.

\section{China}

It is in China's interest to ensure that the relationship with Russia does not delve into something that can be misconstrued as a power play on Western interests. Russia cannot shake the corruption that has infected its government from the top down and while willing to be a part 
of the global community. Russia will continue to play by its own rules and will not be afraid to use shady backroom deals to further its own interests. Perception is reality and the ChinaRussia relationship has already brought frustration to the West. Through the UN, "the two have made common cause in geopolitics. China abstained from a UN Security Council vote in March, 2014, that would have rejected a referendum that Russia backed in Crimea before annexing it. China also joined Russia in vetoing UN attempts to sanction the regime of Bashar Assad fighting a civil war in Syria." (The Economist Intelligence Unit N.A., Inc. 2014).

\section{The United States}

"Compared with the Chinese-Russian relationship, the one between Beijing and Washington is wider and more complicated. Combined, China and the United States account for one-third of global GDP. In 2014, U.S.-Chinese trade reached nearly $\$ 600$ billion, and accumulated mutual investment exceeding \$120 billion" (Ying, 2016). The U.S.-China relationship is crucial to world stability, and the trade relationship between the two remains important to each. The United States needs to understand that China will not accept bloc politics in Asia. The TransPacific Partnership (TPP), championed by the United States, is a 12-country agreement that has excluded China because of their stance on worker's rights and labor protections. By not being able to participate, the outcome of the TPP could have a negative impact on China exports. As noted in Ying's article, "some scholars in China and elsewhere have suggested that if the United States insists on imposing bloc politics on the region, China and Russia should consider responding by forming a bloc of their own. But the Chinese leadership does not approve of such arguments. China does not intend to form such a bloc, either. China and Russia should stick to the principle of partnership rather than build an alliance. As for China and the United States, they should continue pursuing a new model of majorcountry relations and allow dialogue, cooperation, and management of differences to prevail." (Ying, 2016).

\section{CONCLUSION}

China and Russia understand that their relationship is a way to address United States' dominance. This mindset will have lasting impacts on the entire world that are not yet understood and may ultimately be detrimental to western ideology. In the event complications arise because Russia and China form a de facto bloc that results in minimizing United States influence and devalues American currency, what happens? It is in the interest of the United States, who should monitor the relationship closely, that China and Russia continue a healthy relationship that benefits each country regional, rather than globally. The United States, China and Russia need to find mutually shared interests in travel, free global trade, and cooperation against global threats. This will encompass terrorism, climate change and disease. Russia and China in theory benefit equally from their trade relationship.

\section{ACKNOWEDGEMENT}

This article was prepared as a result of research scholarship funded by the Webster University.

\section{REFERENCES}

BBC Monitoring Former Soviet Union. (2014, June 2). Russian analyst comments onsignificance of Putin's visit to China. $B B C$ Monitoring Former Soviet Union. Retrieved from

http://search.proquest.com/docview/1531 044823 ?accountid $=28109$

Chaturvedi, N. (2016, January). How China's Economy Has Evolved. In CNBC. Retrieved from

http://www.cnbc.com/2016/01/17/howchinas-economy-has-evolved-incharts.html

China-Russia Seminar, (2016) New Opportunities $\&$ New Challenges. Retrieved from http://www.pwc.ru/ru/events/2016/chinarussia-2016/russia-china-en.pdf

Ding, Y. (2014, May 29). A historic deal - Putin's Visit Upgrades China-Russia Energy and Security Cooperation. Beijing Review, Retrieved from http://search.proquest.com/docview/1529 542167? accountid $=28109$

Dreyer, June. "China and Russia: The Partnership Deepens - Foreign Policy Research Institute." Foreign Policy Research Institute. N.p., 7 Jan. 2016. Web. 16 Aug. 2016. Retrieved from http://www.fpri.org/article/2016/01/chinaand-russia-partnership-deepens/

The Economist Intelligence Unit N.A., Inc. (2014, 
May 24). Best frenemies; China and Russia. The Economist, 411(8888), 12(US).

Retrieved from

http://ezproxy.hamline.edu:2769/ps/i.do?i $\mathrm{d}=$ GALE\% $/$ CA368950168\&sid=summon\&v= $2.1 \& u=c l i c \_$hamline\&it $=r \& p=E A I M \& s w \Rightarrow w \&$ asid=8957c73f9a248e01dba479c7f2ae634

Gelb, L. H., \& Simes, D. K. (2013). Beware collusion of China, Russia. The National Interest, (126), 5+. Retrieved from http://ezproxy.hamline.edu:2769/ps/i.do?i $\mathrm{d}=$ GALE\%/CA335733285\&sid=summon\&v $=$ $2.1 \& u=c l i c$ hamline\&it $=r \& p=E A I M \& s w=w \&$ asid=8290d6ce80f75a8fae20ce3c133f2ccc

Giannakarou, G. (2014) . The Most Fundamental Problems Afflicting the Multilateral Trade Regime and How they Might be Resolved, JEECAR, Vol1, No2, Retrieved from: http://ieeca.org/journal/index.php/JEECAR/ article/view/75/pdf

Heli S. (2016, June 21). Economic Relations Betw een Russia and china - Increasing Inter-dependence? . Retrieved from http://bruegel.org/wpcontent/uploads/2016/06/Heli-SimolaRussia-China-presentation.pdf

Hsu, J., \& Soong, J. (2014). Development of ChinaRussia Relations (1949-2011). Chinese Economy, 47(3), 70-87. doi:10.2753/CES1097-1475470305

Li, Z. (2014, Oct 16). An evolving partnership china and russia have become increasingly close, but stop short of a military alliance. Beijing Review, Retrieved from http://search.proquest.com/docview/1615 704024 ? accountid $=28109$

Men, J. (2014). Climate change and EU-China partnership: Real ist disguise or institutionalist blessing? Asia Europe Journal, 12(1), 49-62. doi:10.1007/s10308014-0373-y

Mustapha, N. (2014), The Impact of Corruption on GDP per Capita, JEECAR, Vol 1, No2. Retrieved from DOI: http://dx.doi.org/10.15549/jeecar.v1i2.76

Nakano, J., \& Chow, E. C. (2014, August). RussiaChina natural gas pipeline agreement. Pipeline \& Gas Journal, 241(8), 46+. Retrieved from http://ezproxy.hamline.edu:2769/ps/i.do?id $=$ GALE\%CA379640192\&sid=summon\&v $=2$. $1 \& u=c l i c$ hamline\&it $=r \& p=E A I M \& s w=w \&$ \&asi $\mathrm{d}=4986216 \mathrm{bababef562cbd46871760 \textrm {b } 5 8 e e}$
Pahl, S. (2014, November). Relations: Russia, China, EU. Retrieved August 17, 2016, from https://www .rt.com/

Petroleum Economist (September 2015). Russia, China strengthen ties. Petroleum Economist. Retrieved from www.lexisnexis.com/hottopics/Inacademic

Robertson, H. (2013, September). Russia's energy trade with China to quadruple by 2025. Petroleum Economist. Retrieved from www.lexisnexis.com/hottopics/Inacademic

Russian Ministry of Economic Development; Accreditation Systems of Russia and EU (2015, April). Retrieved from http://economy.gov.ru/en/

Recknagel, C. (2015, September 03). Trade Unrequited: Top Russian, Chinese Trading Partners Compared [Digital image].

Retrieved August 12, 2016. Retrieved from http://www.rferl.org/content/russia-putinstatements-belie-chinaproblem/27223282.html

Sidorenko, T (2013, April). The Scope of Economic Cooperation between Russia and China and Future Prospects, Academic Journal.

Retrieved from http://www .probdes.iiec.unam.mx/en/revi stas/v45n176/body/v45n176a2_1.php

Soong, J. (2014). Development of China-Russia Relations (1949-2011). Chinese Economy, 47(3), 70-87. Doi:10.2753/CES10971475470305

Timmerman, K. R. (2001, August 13). China and Russia Align Against U.S. Insight on the News,

17(30), 22. Retrieved from

http://ezproxy.hamline.edu:2769/ps/i.do?i $\mathrm{d}=\mathrm{GALE} \%$ /CA77356320\&sid=summon\& $\mathrm{v}=2$. $1 \& u=c l i c \_$hamline\&it $=r \& p=E A I M \& s w=w \& a$ sid=7ff71f4fd1c902000641d3bcd68d0b17

Ying, F. (2016, February). How China Sees Russia. Foreign Affairs, 95(1), 96. Retrieved from Points of View Reference Center

Weitz, R. (2014). The Russia-China gas deal: implications and ramifications. World Affairs, 1773), 80+. Retrieved from

http://ezproxy.hamline.edu:2769/ps/i.do?id=GAL E\% lic_hamline\&it $=r \& p=E A I M \& s w \Rightarrow w \& a s i d=8 f$ 6c59921dd6a61dade89d0f63c610e93

WTO (2015). In International Trade Statistics. Retrieved from 
https://www.wto.org/english/res_e/statis_ e/its2015_e/its2015_e.pdf

\section{ABOUT THE AUTHORS}

Nikolay Megits email: nikolaymegits45@w ebster.edu

Dr. Nikolay Megits is an expert of global economics, international trade, strategic management, FDI in emerging markets, and entrepreneurship, with a distinguished record of academic achievement in lecturing and scholarly research. He possesses over 25 years of international business experience including strategic planning, sales, and import/export practices. He holds MBA and a Doctorate in Economics. Dr. Megits is an Academic of the Ukrainian Academy of Economic Sciences. 
